\title{
Erratum to: Metabotropic glutamate receptor 5 may be involved in macrophage plasticity
}

Lali Shanshiashvili ${ }^{1,2^{*}}$, Elene Tsitsilashvili ${ }^{1}$, Nino Dabrundashvili ${ }^{3}$, Irine Kalandadze ${ }^{2}$ and David Mikeladze $\mathrm{M}^{1,2}$

\section{Erratum to: Biol Res (2017) 50:4 \\ DOI 10.1186/s40659-017-0110-2}

In the original version of the article [1], Images 1, 2, 3 and 4 were included as Additional file 1: Figure S1, Additional file 2: Figure S2, Additional file 3: Figure S3 and Additional file 4: Figure S4, respectively. The article has now been updated to include Images 1, 2, 3 and 4 in the main body of the article instead.

\section{Author details}

${ }^{1}$ Ilia State University, Tbilisi, Georgia. ${ }^{2}$ I.Beritashvili Center of Experimental Biomedicine, Tbilisi, Georgia. ${ }^{3}$ Institute of Medical Biotechnology, Tbilisi State University, Tbilisi, Georgia.

The online version of the original article can be found under doi:10.1186/s40659-017-0110-2.

Received: 7 March 2017 Accepted: 15 March 2017

Published online: 27 March 2017

\section{Reference}

1. Shanshiashvili L, Tsitsilashvili E, Dabrundashvili N, Kalandadze I, Mikeladze

D. Metabotropic glutamate receptor 5 may be involved in macrophage plasticity. Biol Res. 2017;50:4. doi:10.1186/s40659-017-0110-2.

\footnotetext{
*Correspondence: lali_shanshiashvili@iliauni.edu.ge

${ }^{1}$ Ilia State University, Tbilisi, Georgia

Full list of author information is available at the end of the article
} 